\title{
Peningkatan keterampilan mengonstruksi teks negosiasi melalui model problem based learning pada peserta didik kelas X MIPA 2 SMA Negeri 7 Malang
}

\author{
Wening Suryandari ${ }^{a, 1^{*}}$, Gigit Mujianto ${ }^{b, 2}$, Laili Ivana ${ }^{c, 3}$ \\ ${ }^{\text {a }}$ PPG Prajabatan Pendidikan Bahasa Indonesia, FKIP, Universitas Muhammadiyah Malang \\ ${ }^{\mathrm{b}}$ Pendidikan Bahasa Indonesia, FKIP, Universitas Muhammadiyah Malang \\ 'SMA Negeri 7 Malang \\ ${ }^{1}$ wening.suryandari23@gmail.com *; ${ }^{2}$ gigit@umm.ac.id; vei_na@,yahoo.co.id \\ *korespondensi penulis
}

\begin{tabular}{ll}
\hline Informasi artikel & \\
\hline Sejarah artikel: & \\
Diterima & 2 Maret 2019 \\
Revisi & 5 April 2019 \\
Dipublikasikan & 20 April 2019 \\
\hline
\end{tabular}

Kata kunci:

Keterampilan

Mengonstruksi

Problem based learning

Teks negosiasi \begin{abstract}
ABSTRAK
Penelitian ini mendeskripsikan penerapan model pembelajaran problem based learning (PBL) sebagai solusi untuk meningkatkan keterampilan mengonstruksi teks negosiasi peserta didik kelas X MIPA 2 SMA Negeri 7 Malang. Tujuan dari penelitian ini adalah untuk mendeskripsikan kualitas proses pembelajaran mengonstruksi teks negosiasi dengan menggunakan model problem based learning, mendeskripsikan peningkatan keterampilan mengonstruksi teks negosiasi dengan model problem based learning, dan mendeskripsikan perubahan tingkah laku peserta didik setelah proses pembelajaran dengan model problem based learning. Penelitian tindakan kelas ini menggunakan desain penelitian deskriptif kualitatif yang dilakukan dalam tiga tahap, yaitu prasiklus, siklus I dan siklus II. Hasil penelitian menunjukkan bahwa penerapan model problem based learning (PBL) mampu meningkatkan keterampilan mengonstruksi teks negosiasi peserta didik kelas X MIPA 2 SMA Negeri 7 Malang. Kemampuan peserta didik dalam berpikir kritis saat mengonstruksi teks pun semakin meningkat. Melalui model pembelajaran problem based learning (PBL) peserta didik tidak diajarkan berandai-andai namun diarahkan untuk mampu menyelesaikan permasalahannya sendiri melalui negosiasi yang dituangkan dalam sebuah teks yang lengkap sesuai dengan struktur dan kebahasaan teks negosiasi. Oleh karena itu, penerapan model problem based learning (PBL) mampu meningkatkan keterampilan mengonstruksi teks negosiasi sebesar 7,22\% pada siklus pertama dan $14,50 \%$ pada siklus kedua dan mengubah tingkah laku peserta didik ke arah yang positif.
\end{abstract}

Key word:

Skills

Construction

Problem based learning

Negotiation text

\begin{abstract}
This study describes the application of the problem based learning (PBL) learning model as a solution to improve the skills of constructing the negotiating text of students of class X MIPA 2 Malang 7 High School. The purpose of this study is to describe the quality of the learning process in constructing negotiating texts using the problem based learning model, describing improvement in skills in constructing negotiating texts with problem based learning models, and describing changes in students' behavior after the learning process with problem based learning models. This class action research uses descriptive qualitative research design carried out in three stages, namely pre-cycle, cycle I and cycle II. The results showed that the application of the problem based learning (PBL) model was able to improve the skills of constructing the negotiating text of students of class X MIPA 2 Malang 7 High School. The ability of students to think critically when constructing text also increases. Through the problem based learning (PBL) learning model students are not taught to be wishful but directed to be able to solve their own problems through negotiations as outlined in a complete text in accordance with the structure and language of the negotiating text. Therefore, the application of the problem based learning (PBL) model was able to improve the skills of constructing the negotiation text by $7.22 \%$ in the first cycle and $14.50 \%$ in the second cycle and changing the behavior of students in a positive direction.
\end{abstract}

Copyright (C) 2019 Universitas Ahmad Dahlan 


\section{Pendahuluan}

Pembelajaran Bahasa Indonesia kurikulum 2013 berbeda dengan kurikulum sebelumsebelumnya, jika pada kurikulum sebelumsebelumnya empat keterampilan berbahasa diajarkan secara terpisah dalam berbagai teks yang berbeda. Pada kurikulum 2013 peserta didik diharapkan mampu menerapkan keempat keterampilan dalam setiap teks yang dipilih menjadi bahan ajar di sekolah. Pemilihan teks dalam kurikulum 2013 sesuai dengan tujuan dan fungsi sosial yang berkaitan erat dengan kebutuhan peserta didik. Bahasa Indonesia bukan hanya diajarkan sebagai pengetahuan bahasa, namun yang lebih utama, yaitu sebagai teks yang memiliki fungsi sebagai sumber aktualisasi diri baik pada konteks sosial maupun budaya akademis. Teks dalam kurikulum 2013 merupakan satuan bahasa utuh yang mengungkapkan makna secara kontekstual. Permendikbud Nomor 69 Tahun 2013 menjelaskan tentang kurikulum 2013 dirancang untuk mempersiapkan generasi muda Indonesia agar beriman, produktif, kreatif, inovatif, dan afektif serta mampu berkontribusi pada kehidupan bermasyarakat, berbangsa, bernegara, dan peradaban dunia. Oleh karena itu, kurikulum 2013 berusaha keras untuk mengembangkan keseimbangan antara sikap spiritual dan sosial, berpikir kritis, kreativitas. Kurikulum 2013 juga berusaha mengembangkan sikap, pengetahuan, dan keterampilan peserta didik hingga mampu menerapkannya dalam berbagai situasi di sekolah dan masyarakat. Pada mata pelajaran Bahasa Indonesia peserta didik diharuskan untuk aktif dalam proses pembelajaran, peserta didik harus mampu mengembangkan pengetahuan secara mandiri dengan bantuan buku maupun internet, peserta didik juga diharapkan mampu merepresentasikan hasil belajarnya dalam wujud nyata baik dalam sebuah karya maupun diterapkan langsung dalam kehidupan peserta didik di akhir pembelajaran.

Karya peserta didik dapat berwujud lisan maupun tulisan. Bentuk lisan dapat dilihat dari materi seperti debat, membaca puisi, negosiasi lisan, dan lain-lain. Karya bentuk tulisan sangat banyak seperti biografi, eksplanasi, laporan hasil observasi, dan negosiasi tulis. Karya dalam bentuk tulisan dalam kompetensi dasar kurikulum 2013 diwujudkan dalam kata kerja mengonstruksi. Selama ini peserta didik masih menganggap kegiatan mengonstruksi sebuah teks merupakan suatu pembelajaran yang tidak menarik dan sulit dilakukan. ketidakmenarikan dan kesulitan tersebut muncul dari diri peserta didik tidak hanya disebabkan oleh peserta didik itu sendiri tetapi juga disebabkan oleh guru yang belum berhasil membuat peserta didik tertarik terhadap pembelajaran Bahasa Indonesia terutama pembelajaran mengonstruksi teks yang merupakan suatu kegiatan yang ekspresif dan produktif. Keterampilan mengonstruksi tidak dapat diperoleh secara langsung dan otomatis, namun harus melalui proses latihan dan praktik yang teratur serta terus menerus (Tarigan, 2008). Keterampilan mengonstruksi teks tidak serta merta dapat dilakukan, namun harus dengan latihan yang rutin dan teratur. Melalui hasil observasi serta wawancara terhadap guru bahasa Indonesia kelas $\mathrm{X}$ di SMA Negeri 7 Malang, terdapat beberapa permasalahan yang ditemui oleh guru dalam pembelajaran mengonstruksi. Masalah yang dihadapi oleh guru yaitu, peserta didik menganggap kegiatan mengonstruksi sulit dilakukan. Kesulitan tersebut disebabkan beberapa faktor, yaitu minat membaca peserta didik yang rendah, kemampuan merangkai kalimat yang kurang, rasa malas untuk menuangkan ide atau gagasan dalam bentuk tulisan, kemampuan berpikir kritis menghadapi permasalahan di sekitar yang masih kurang, dan daya kreativitas pemecahan masalah yang belum maksimal. Ditambah dengan program UKBM yang harus diterapkan di SMA Negeri 7 Malang menjadikan guru tidak dapat menerapkan berbagai model pembelajaran yang sesuai untuk pembelajaran mengonstruksi. Oleh sebab itu, peserta didik semakin mengalami kesulitan dalam mengonstruksi suatu teks.

Terdapat lima materi teks yang peserta didik pelajari pada kelas X. Berdasarkan hasil wawancara dengan guru menunjukkan bahwa teks negosiasi menjadi salah satu teks yang perlu mendapat perhatian khusus. Teks negosiasi merupakan teks yang bertujuan untuk mencapai kesepakatan, yang memiliki struktur dan kaidah kebahasaan tersendiri dibanding dengan teks lainnya. Menurut Sutrisno dan Kusmawan (2007) negosiasi merupakan proses komunikasi antara penjual dan calon pembeli yang dilakukan secara perorangan maupun kelompok yang di dalamnya terjadi proses diskusi dan perundingan untuk mencapai kesepakatan tujuan yang saling menguntungkan kedua belah pihak. Sedangkan menurut Pruitt (dalam Lewicki, 2012) negosiasi merupakan suatu bentuk pengambilan keputusan antara dua pihak atau lebih dengan berbicara satu sama lain dalam upaya untuk menyelesaikan kepentingan perdebatan mereka. Berdasarkan hakikat negosiasi tersebut dapat dilihat bahwa teks negosiasi merupakan sebuah teks yang kompleks dengan tujuan untuk mencapai kesepakatan bersama yang harus dibuat dengan bahasa negosiasi yang baik. 
Sebagian besar peserta didik kesulitan dalam penggunaan bahasa negosiasi dan topik negosiasi yang akan dibuat. Nilai peserta didik dalam mengonstruksi teks negosiasi pada kegiatan prasiklus masih dalam kategori rendah dengan nilai rata-rata kelas, yaitu 69,26 dengan batas ketuntasan 75. Nilai rata-rata tersebut termasuk dalam kategori kurang karena peserta didik belum memahami secara benar tentang teks negosiasi dan peserta didik kurang menyukai pembelajaran mengonstruksi teks negosiasi dengan sistem UKBM.

Peneliti dan guru berusaha meningkatkan kemampuan mengonstruksi teks negosiasi dengan alasan setiap orang pasti akan melakukan proses negosiasi dalam kehidupannya begitu pula peserta didik SMA juga harus mampu bernegosiasi dengan baik dalam kehidupannya baik dalam lingkungan sekolah maupun masyarakat bahkan dapat selalu menerapkan dalam kehidupan yang akan datang. Negosiasi merupakan kegiatan yang sangat penting di negara Indonesia yang beraneka ragam suku dan budaya, melalui negosiasi suatu permasalahan dapat diselesaikan dengan baik dan meminimalkan kerugian kedua belah pihak. Selain negosiasi penyelesaian masalah juga banyak aspek kehidupan yang membutuhkan negosiasi seperti dalam hal jual beli, tawar menawar dengan orang tua ketika meminta sesuatu, bahkan di dunia kerja nantinya juga sangat banyak. Oleh karena itu, peneliti dan guru sangat tertarik untuk meningkatkan kemampuan peserta didik dalam bernegosiasi. Dalam buku peserta didik mata pelajaran Bahasa Indonesia Kurikulum 2013 (Kementerian Pendidikan dan Kebudayaan, 2013) dijelaskan bahwa teks negosiasi merupakan bentuk interaksi sosial yang berfungsi untuk mencari penyelesaian bersama di antara pihakpihak yang mempunyai perbedaan kepentingan. Pihak-pihak tersebut berusaha menyelesaikan perbedaan itu dengan cara-cara yang baik tanpa merugikan salah satu pihak. Negosiasi juga dapat terjadi sebagai tanggapan terhadap usulan program dari pihak pertama kepada pihak kedua. Agar usulan itu menguntungkan kedua belah pihak, wakil dari setiap pihak perlu bertemu untuk melakukan negosiasi. Menyikapi permasalahan mengenai teks negosiasi tersebut, sangat dibutuhkan suatu model pembelajaran yang tepat dalam mengonstruksi teks negosiasi. Suatu model pembelajaran yang dapat membantu peserta didik untuk tertarik dengan materi negosiasi, dan selanjutnya mempermudah peserta didik dalam mengonstruksi teks negosiasi.

Model pembelajaran yang ada sangat banyak dan beragam. Pemilihan model pembelajaran tidak dapat dilakukan tanpa banyak pertimbangan sehingga peneliti dan guru memilih model pembelajaran berbasis masalah atau problem based learning (PBL) untuk meningkatkan keterampilan mengonstruksi teks negosiasi, dengan berbagai alasan diantaranya pembelajaran berbasis masalah dapat mengembangkan kemampuan peserta didik berpikir kritis dan kreatif, seperti harapan pada kurikulum 2013. Selain itu, model problem based learning sesuai dengan pembelajaran bahasa Indonesia khususnya teks negosiasi yang merupakan sebuah teks dengan maksud menyelesaikan suatu masalah melalui cara yang terstruktur dan sistematis. Melalui sintagmatik model problem based learning akan memudahkan peserta didik menemukan masalah pribadi dan diselesaikan melalui negosiasi secara sistematis. Menurut Sanjaya (2006) problem based learning merupakan model pembelajaran yang menekankan pada proses penyelesaian masalah yang dihadapi secara ilmiah. Sependapat dengan Sanjaya, Barron (dalam Huda, 2014) juga menyatakan bahwa pembelajaran berbasis masalah sebagai pembelajaran yang diperoleh melalui proses menuju pemahaman terhadap resolusi suatu masalah. Sesuai dengan hakikat dari pembelajaran berbasis masalah, yaitu melatih dan mengembangkan kemampuan untuk menyelesaikan masalah yang berorientasi pada masalah otentik dari kehidupan aktual peserta didik demi merangsang kemampuan berpikir tingkat tinggi sangat sesuai diterapkan dalam pembelajaran mengonstruksi teks negosiasi. Selain itu model pembelajaran problem based learning juga memiliki beberapa keunggulan yang diuraikan oleh Sanjaya (2006) antara lain: (1) Pemecahan masalah dapat menantang kemampuan peserta didik serta memberikan kepuasan untuk menemukan pengetahuan yang baru. (2) Pemecahan masalah dapat meningkatkan aktivitas pembelajaran peserta didik. (3) Pemecahan masalah dapat membantu peserta didik mentransfer pengetahuan mereka untuk memahami masalah dalam kehidupan nyata. (4) Pemecahan masalah dapat membantu peserta didik mengembangkan pengetahuan barunya dan bertanggungjawab dalam pembelajaran yang lakukan, (5) Pemecahan masalah juga dapat mendorong untuk melakukan evaluasi secara mandiri baik terhadap hasil maupun proses belajarnya, (6) Pemecahan masalah dapat mengembangkan kemampuan peserta didik untuk berpikir kritis dan mengembangkan kemampuan untuk menyesuaikan dengan pengetahuan baru, (7) Pemecahan masalah dapat memberikan kesempatan peserta didik untuk mengaplikasikan pengetahuan dalam dunia nyata.

Dalam pelaksanaan pembelajaran dengan model problem based learning (PBL) kondisi yang harus tetap dijaga adalah suasana yang kondusif, terbuka, demokratis, serta suasana nyaman dan menyenangkan 
agar peserta didik dapat berpikir secara optimal. Penerapan model pembelajaran problem based learning (PBL) juga telah banyak diterapkan untuk mengatasi permasalahan mengenai motivasi belajar di sekolah, salah satunya penelitian yang dilakukan oleh Argaw, dkk. (2016) yang menerapkan model problem based learning (PBL) di salah satu sekolah di Ethiopia terbukti meningkatkan motivasi belajar dan keterampilan pemecahan masalah pada mata pelajaran fisika. Khoo Yin Yin (2011) juga melakukan penelitian eksperimental menggunakan model problem based learning (PBL) di sepuluh sekolah di Malaysia untuk mengukur kemampuan peserta didik dalam menyelesaikan masalah. Kesepuluh sekolah tersebut dibagi menjadi kelas eksperimen dan kelas kontrol. Kelas eksperimen diberikan perlakukan dengan model problem based learning. Hasil penelitian tersebut menunjukkan bahwa terdapat perbedaan yang signifikan antara kelas yang diberikan model problem based learning dangan kelas kontrol. Berdasarkan penelitianpenelitian terdahulu tersebut, peneliti berusaha untuk mengatasi masalah terkait pembelajaran mengonstruksi teks negosiasi menggunakan model problem based learning (PBL) dengan sebuah penelitian yang berjudul "Peningkatan Pembelajaran Mengonstruksi Teks Negosiasi melalui Model Problem Based Learning Peserta Didik Kelas X MIPA 2 SMA Negeri 7 Malang”.

\section{Metode}

Penelitian mengenai penerapan model pembelajaran problem based learning dalam pembelajaran mengonstruksi teks negosiasi ini merupakan penelitian tindakan kelas (PTK). Subyantoro (2012) menuturkan bahwa penelitian tindakan kelas adalah suatu penelitian yang dilakukan secara sistematis dan reflektif terhadap berbagai tindakan yang dilakukan oleh guru di dalam kelas. Desain penelitian tindakan kelas yang digunakan dalam penelitian ini mendasarkan pada pandangan Kemmis dan Tagrat seperti pada gambar 1 .

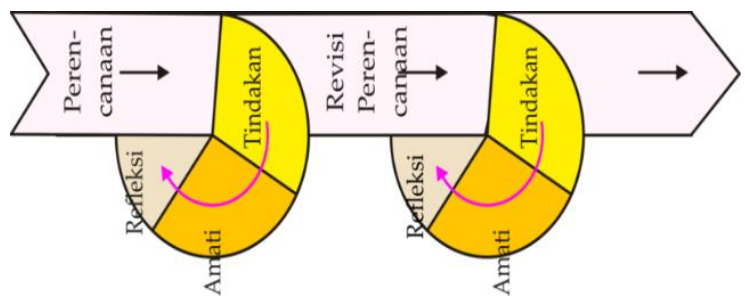

Gambar 1. Model PTK Kemmis dan Tagart
Subjek dalam penelitian ini adalah keterampilan mengonstruksi teks negosiasi dengan model problem based learning pada peserta didik kelas X MIPA 2 SMA Negeri 7 Malang. Instrumen penelitian yang digunakan berupa instrumen tes dan nontes. Teknik analisis data terdiri atas teknik kualitataif dan kuantitatif. Data kuantitatif diperoleh menggunakan teknik penyekoran dengan rumus 1 .

$\mathrm{NP}=\frac{\left(\sum \mathrm{xi}\right)}{\mathrm{N}}$

Keterangan:

NP : Nilai persentase tiap interval

$\sum x i \quad$ Jumlah frekuensi tiap interval

$\mathrm{N} \quad$ : Jumlah nilai total maksimal

Untuk menghitung nilai rata-rata tiap aspek, maka digunakan rumus 2 .

$X=\frac{\left(\sum \mathrm{xi}\right)}{\mathrm{N}}$

Keterangan:

$\mathrm{X} \quad$ : Nilai rata-rata hasil tes

$\sum x i \quad$ : Jumlah bobot skor tiap aspek

$\mathrm{N} \quad$ : Jumlah responden dalam satu kelas

(Sudjana, 2005)

Keberhasilan penelitian dapat diketahui dari persentase peserta didik yang mendapat nilai memenuhi KKM yang diterapkan di SMA N 7 Malang, yaitu 75. Penelitian ini dapat dikatakan berhasil apabila persentase nilai peserta didik meningkat pada setiap siklus yang dilakukan.

\section{Hasil dan pembahasan}

Berdasarkan hasil pembelajaran yang telah dilakukan pada prasiklus, siklus I, dan siklus II, dapat diketahui bahwa telah terjadi peningkatan proses pembelajaran mengonstruksi teks negosiasi, peningkatan keterampilan mengonstruksi teks negosiasi, dan peningkatan sikap atau tingkah laku peserta didik ke arah yang positif. Pembahasan hasil tersebut dijabarkan dari hasil pengamatan dan analisis terhadap proses pembelajaran, hasil tes, dan nontes. Proses pembelajaran dan perubahan perilaku mengacu pada pelaksanaan proses pembelajaran mengonstruksi teks negosiasi dengan model problem based learning menggunakan instrumen nontes yang mengacu pada hasil perolehan sikap dan motivasi peserta didik melalui observasi, wawancara, dan angket. Peningkatan keterampilan mengonstruksi teks negosiasi diperoleh dari nilai yang dicapai 
peserta didik dalam mengonstruksi teks negosiasi setelah diberlakukan model problem based learning.

Pelaksanaan Pembelajaran Mengonstruksi Teks Negosiasi melalui Model Problem Based Learning pada Peserta Didik Kelas X MIPA 2 SMA Negeri 7 Malang

Proses pembelajaran mengonstruksi teks negosiasi penelitian ini dilakukan sebanyak tiga tahap, yaitu prasiklus, siklus I, dan siklus II. Penelitian prasiklus dilakukan untuk mengetahui kondisi awal peserta didik dalam pembelajaran mengonstruksi teks negosiasi. Proses pembelajaran mengonstruksi teks negosiasi pada prasiklus guru tidak menggunakan model pembelajaran maupun pendekatan pembelajaran tertentu. Pembelajaran prasiklus dilakukan dengan proses Unit Kegiatan Belajar Mandiri (UKBM) seperti yang telah diterapkan pada semua pembelajaran di SMA Negeri 7 Malang. Pada siklus I dan siklus II peneliti menggunakan model pembelajaran model problem based learning. Berikut ini proses pembelajaran pada siklus I dan siklus II.

Pada siklus I dan siklus II proses pembelajaran mengonstruksi teks negosiasi dengan model pembelajaran model problem based learning melalui beberapa langkah, yaitu kegiatan awal, kegiatan inti, dan kegiatan akhir. Adapun langkah pembelajaran pada kegiatan awal, yaitu (1) guru memulai pembelajaran dengan mengucapkan salam, (2) guru mengondisikan peserta didik untuk siap mengikuti pembelajaran, (3) guru mengecek kehadiran peserta didik, dan (4) guru menyampaikan kompetensi dasar yang akan dicapai, tujuan pembelajaran, dan langkahlangkah pembelajaran yang akan dilaksanakan. Pada kegiatan inti terdiri atas mengorientasi peserta didik pada masalah, mengorganisasikan kegiatan pembelajaran, membimbing penyelidikan mandiri dan kelompok, mengembangkan dan menyajikan hasil karya, dan analisis dan evaluasi proses pemecahan masalah. Tahap mengorientasi peserta didik pada masalah, langkah pembelajaran yang dilaksanakan, yaitu (1) Peserta didik melakukan pengamatan terhadap kehidupan sosial di sekitar baik lingkungan rumah maupun sekolah, (2) Peserta didik mendata permasalahan-permasalahan yang perlu diselesaikan melalui negosiasi. Tahap mengorganisasikan kegiatan pembelajaran, langkah pembelajaran yang dilaksanakan, yaitu (1) Peserta didik dikelompokkan untuk bertukar informasi permasalahan yang telah ditemukan, (2) Peserta didik menyampaikan berbagai pertanyaan (atau menanya) terhadap masalah yang sedang dikaji, (3) Peserta didik yang belum menemukan permasalahan diharapkan dapat terpancing dan sanggup menemukan permasalahan yang pernah dialami sendiri. Tahap membimbing penyelidikan mandiri dan kelompok, langkah pembelajaran yang dilaksanakan, yaitu (1) Peserta didik diberikan contoh teks negosiasi dalam bentuk dialog yang diambil dari permasalahan yang familier dengan peserta didik (telaah model supaya peserta didik tidak lupa dengan struktur dan kebahasaan teks negosiasi), (2) Peserta didik menentukan permasalahan yang dipilih untuk dikembangkan menjadi teks negosiasi. Tahap mengembangkan dan menyajikan hasil karya, langkah pembelajaran yang dilaksanakan, yaitu (1) Peserta didik mengonstruksi teks negosiasi berdasarkan permasalahan yang ingin diselesaikan melalui negosiasi secara individu, (2) Peserta didik menyelesaikan teks negosiasi dengan memerhatikan struktur dan kebahasaan teks negosiasi. Tahap analisis dan evaluasi proses pemecahan masalah, langkah pembelajaran yang dilaksanakan, yaitu (1) Peserta didik menukarkan hasil teks negosiasi untuk dikoreksi struktur dan kebahasaan dan ejaannya, (2) Peserta didik saling mengoreksi, (3) Peserta didik mendemonstrasikan teks negosiasi di depan kelas. Kegiatan yang dilakukan pada tahap akhir yaitu (1) guru dan peserta didik menyimpulkan pembelajaran mengonstruksi teks negosiasi, (2) Peserta didik dan guru melakukan refleksi pembelajaran, (3) Guru memberikan tindak lanjut untuk pertemuan berikutnya mengenai mendemonstrasikan teks negosiasi yang sudah ditulis, dan (4) guru menutup pembelajaran dengan doa.

Perbedaan selama proses pembelajaran yang dilakukan pada siklus I dan siklus II dapat dilihat pada bagian inti pembelajaran, yaitu pada tahap mengorientasi peserta didik pada masalah jika pada siklus I langkah pembelajaran yang dilaksanakan pada tahap mengorientasi peserta didik pada masalah adalah guru menyiapkan beberapa masalah yang dapat diselesaikan melalui negosiasi yang dekat dengan peserta didik, yaitu peternakan di dekat perkampungan warga mencemari lingkungan, ditilang polisi karena lupa membawa SIM, pengajuan proposal lomba bulan bahasa di sekolah, menjual kerajinan tangan hasil karya kelompok pada mata pelajaran kewirausahaan. (kerajinan dapat berupa vas bunga, gelang, bunga hias, dll), dan membeli seragam paskibra dan perlengkapannya di pasar besar. Maka pada siklus II tahap mengorientasi peserta didik pada masalah diubah menjadi peserta didik menemukan sendiri permasalahan yang terjadi di lingkungan yang perlu diselesaikan dengan proses negosiasi dan membuat teks negosiasi berdasarkan permasalahan tersebut.

Proses pembelajaran mengonstruksi teks negosiasi dengan model pembelajaran problem based 
learning pada siklus I dan siklus II, peserta didik merasa tertarik, antusias dan lebih bersemangat dalam kegiatan pembelajaran karena selama ini guru dalam mengajar dengan menggunakan UKBM (Unit kegiatan Belajar Mandiri) sistem sks yang baru diterapkan di kota Malang. UKBM hanya berisi perintah-perintah yang harus dikerjakan peserta didik sehingga peserta didik tidak merasakan proses pembelajaran yang menarik dan mampu mengasah pendidikan karakter yang menjadi standar penilaian pada kurikulum 2013. Sistem UKBM yang telah diterapkan di SMA Negeri 7 Malang juga sangat membatasi keaktifan peserta didik dan keberanian peserta didik untuk mengungkapkan pertanyaanpertanyaan secara lisan dalam proses pembelajaran karena peserta didik sibuk untuk menyelesaikan tugas-tugas supaya cepat menempuh UKBM selanjutnya. Dengan sistem UKBM keindividualisan peserta didik semakin tampak sehingga karakter gotong royong yang diharapkan dalam kurikulum 2013 justru tidak dapat diwujudkan. Dengan model problem based learning yang di dalam prosesnya terdapat kegiatan berkelompok membantu peserta didik untuk mampu berkomunikasi sehingga dapat mewujudkan karakter komunikatif dan peduli sosial. Pembelajaran dengan model problem based learning juga yang membuat peserta didik tidak merasa bosan dan jenuh selama proses pembelajaran, sehingga peserta didik merasa senang dan bersemangat dalam pembelajaran mengonstruksi teks negosiasi.

Peningkatan Keterampilan Mengonstruksi Tek Negosiasi Peserta Didik Kelas X MIPA 2 SMA Negeri 7 Malang setelah Mengikuti Pembelajaran dengan Model Problem Based Learning

Berdasarkan hasil tes mengonstruksi teks negosiasi dengan model pembelajaran problem based learning diperoleh hasil bahwa nilai peserta didik kelas X MIPA 2 SMA Negeri 7 Malang mengalami peningkatan. Peningkatan tersebut dapat diketahui dari pencapaian nilai rata-rata yang diperoleh peserta didik pada prasiklus, siklus I, dan siklus II. Nilai rata-rata pada prasiklus dari 69.26 menjadi 74,26 pada siklus I, sehingga mengalami peningkatan sebesar 7,22\%. Dari siklus I dengan nilai rata-rata 74,26 menjadi 85,03 pada siklus II, sehingga mengalami peningkatan sebesar $14.50 \%$. Dengan demikian, dapat diketahui bahwa model pembelajaran problem based learning dapat meningkatkan keterampilan mengonstruksi teks negosiasi pada setiap siklusnya dengan persentase yang selalu meningkat. Pembahasan hasil penelitian dapat diketahui dari hasil prasiklus, siklus I, dan siklus II. Pembahasan hasil tes berpedoman pada pemerolehan skor yang dicapai peserta didik pada tes mengonstruksi teks negosiasi. Aspek-aspek yang diterapkan dalam penilaian hasil mengonstruksi teks negosiasi, yaitu (1) struktur teks negosiasi, (2) kebahasaan teks negosiasi, (3) isi teks negosiasi, (4) ejaan dan tanda baca, dan (5) kekreatifan ide pemecahan masalah. Aspek tersebut diakumulasikan untuk mendapatkan hasil tes mengonstruksi teks negosiasi pada prasiklus, siklus I, dan siklus II seperti pada tabel 1 .

Tabel 1 Peningkatan hasil keterampilan mengonstruksi teks negosiasi prasiklus, siklus I, dan siklus II

\begin{tabular}{|c|c|c|c|c|}
\hline \multirow[b]{2}{*}{$\begin{array}{l}\mathrm{N} \\
\mathrm{o}\end{array}$} & \multirow[b]{2}{*}{ Aspek } & \multicolumn{3}{|c|}{ Rata-rata } \\
\hline & & Prasiklus & $\begin{array}{c}\text { Siklus } \\
1\end{array}$ & $\begin{array}{c}\text { Siklus } \\
2\end{array}$ \\
\hline 1 & $\begin{array}{l}\text { Struktur teks } \\
\text { negosiasi }\end{array}$ & 14,54 & 15,32 & 16,21 \\
\hline 2 & $\begin{array}{c}\text { Kebahasaan teks } \\
\text { negosiasi }\end{array}$ & 15,67 & 16,21 & 18,54 \\
\hline 3 & Isi teks negosiasi & 14,67 & 15,78 & 18,12 \\
\hline 4 & $\begin{array}{c}\text { Ejaan dan tanda } \\
\text { baca }\end{array}$ & 13,76 & 14,56 & 16,88 \\
\hline 5 & $\begin{array}{c}\text { Kekreatifan ide } \\
\text { pemecahan masalah }\end{array}$ & 10,62 & 12,39 & 15,28 \\
\hline & Nilai Akhir & 69,26 & 74,26 & 85,03 \\
\hline
\end{tabular}

Berdasarkan Tabel 1 tersebut hasil tes keterampilan mengonstruksi teks negosiasi dari prasiklus, siklus I, siklus II, dan siklus III dapat dijelaskan bahwa keterampilan mengonstruksi teks negosiasi pada setiap aspek penilaian mengalami peningkatan, Hasil tes mengonstruksi teks negosiasi pada prasiklus diperoleh nilai rata-rata 69,26 dengan kategori kurang pada rentang nilai 61-70, nilai tersebut diperoleh dari lima aspek penilaian, pada aspek struktur teks negosiasi memperoleh nilai rata-rata 14,24 dengan kategori cukup baik, aspek kebahasaan teks negosiasi memperoleh nilai rata-rata 15,67 dengan kategori baik, aspek isi teks negosiasi memperoleh nilai rata-rata 14,67 dengan kategori cukup baik, aspek ejaan dan tanda baca memperoleh nilai rata-rata 13,76 dengan kategori cukup baik, dan aspek kekreatifan ide pemecahan masalah memperoleh nilai rata-rata 10,26 dengan kategori kurang. Hasil keterampilan mengonstruksi teks negosiasi pada setiap aspek pada siklus I diperoleh nilai rata-rata 74,26 dengan kategori cukup baik pada rentang nilai 71-80, nilai tersebut diperoleh dari lima aspek penilaian. Pada aspek struktur teks negosiasi memperoleh nilai rata-rata 15,32 dengan kategori baik, aspek kebahasaan teks negosiasi memperoleh nilai rata-rata 16,21 dengan kategori sangat baik, aspek isi teks negosiasi memperoleh nilai rata-rata 15,78 dengan kategori baik, aspek ejaan serta tanda baca memperoleh nilai rata-rata 14,56 
dengan kategori cukup baik, dan aspek kekreatifan ide pemecahan masalah memperoleh nilai rata-rata 12,39 dengan kategori cukup baik, Dengan demikian, diketahui peningkatan dari prasiklus ke siklus I mencapai 7,22\%, Hasil tes mengonstruksi teks negosiasi pada siklus II diperoleh nilai rata-rata 85,03 dengan kategori baik pada rentang nilai 8190, nilai tersebut diperoleh dari kelima aspek penilaian. Pada aspek struktur teks negosiasi memperoleh nilai rata-rata 16,21 dengan kategori sangat baik, aspek kebahasaan teks negosiasi memperoleh nilai rata-rata 18,54 dengan kategori sangat baik, aspek isi teks negosiasi memperoleh nilai rata-rata 18,12 dengan kategori sangat baik, aspek ejaan serta tanda baca memperoleh nilai rata-rata 16,88 dengan kategori sangat baik, dan aspek kekreatifan ide pemecahan masalah memperoleh nilai rata-rata 15,28 dengan kategori baik, Dengan demikian, diketahui peningkatan dari siklus I ke siklus II mencapai 14,50\%.

Peningkatan nilai rata-rata tiap aspek pada prasiklus, siklus I, dan siklus II setelah pembelajaran menggunakan model pembelajaran problem based learning dapat meningkatkan keterampilan mengonstruksi teks negosiasi peserta didik kelas X MIPA 2 SMAN 7 Malang. Dengan demikian, dapat disimpulkan bahwa model pembelajaran problem based learning dapat meningkatkan keterampilan mengonstruksi teks negosiasi peserta didik kelas X MIPA 2 SMAN 7 Malang. Peningkatan dari prasiklus, siklus I dan siklus II juga dapat dilihat pada gambar 2 .

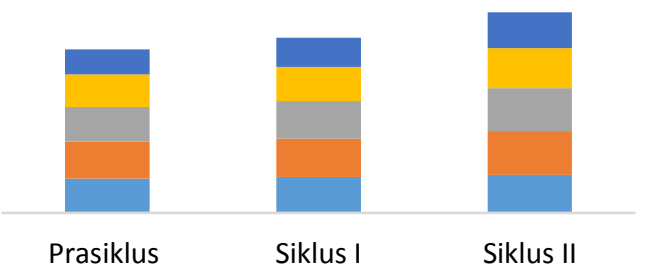

Kekreatifan ide pemecahan masalah

Ejaan dan tanda baca

- Isi teks negosiasi

Kebahasaan teks negosiasi

- Strukstur teks negosiasi

Gambar 2. Peningkatan keterampilan mengonstruksi teks negosiasi

Pada diagram tersebut jelas terlihat peningkatan mengonstruksi teks negosiasi pada aspek kekreatifan ide dan pemecahan masalah, ejaan dan tanda baca, isi teks, kebahasaan teks, dan struktur teks. Kekreatifan ide memiliki peningkatan yang cukup tinggi disebabkan model problem based learning yang diterapkan. Hal tersebut disebabkan peserta didik mulai terbuka pikirannya untuk menemukan permasalahan di lingkungan sekitar yang mampu diselesaikan melalui negosiasi.

Perubahan Perilaku Peserta Didik Kelas X MIPA 2 SMA Negeri 7 Malang setelah Mengikuti Pembelajaran Mengonstruksi Teks Negosiasi dengan Model Pembelajaran Problem Based Learning

Penelitian ini tidak hanya meneliti keterampilan mengonstruksi teks negosiasi tetapi juga meneliti perubahan perilaku peserta didik setelah mengikuti pembelajaran mengonstruksi teks negosiasi menggunakan model pembelajaran problem based learning. Perilaku peserta didik yang sebelumnya cenderung acuh tak acuh dengan pembelajaran yang dilakukan dan tidak terkondisikan dengan baik dalam pembelajaran prasiklus, ternyata dapat diubah ke arah yang positif saat pembelajaran siklus I dan siklus II. Hal ini dapat diketahui dari hasil nontes siklus I dan siklus II meliputi observasi, wawancara, dan angket. Berdasarkan hasil observasi perubahan perilaku peserta didik dapat diketahui perubahan sikap dan motivasi peserta didik secara keseluruhan mengalami peningkatan. Peningkatan tersebut dapat diketahui dengan perubahan sikap peserta didik yang selama ini dalam pembelajaran mengonstruksi teks negosiasi peserta didik tidak sepenuhnya konsentrasi terhadap pembelajaran dengan sibuk bermain gawai, setelah penerapan model pembelajaran problem based learning peserta didik dapat bersungguhsungguh mengikuti proses pembelajaran dan menikmati proses pembelajaran. Adapun peserta didik yang selama ini kurang aktif dalam proses pembelajaran, setelah penerapan model pembelajaran problem based learning peserta didik mengalami perubahan, sehingga peserta didik aktif bertanya dan mencari tahu terkait materi negosiasi. Ketika peserta didik disuruh untuk mengerjakan lembar kerja peserta didik bersungguh-sungguh dalam mengerjakan tugas. Selain observasi terhadap perubahan sikap peserta didik selama proses pembelajaran terdapat peningkatan juga dalam hal motivasi belajar peserta didik. Peningkatan tersebut dapat diketahui dengan peserta didik yang selama ini kurang tertarik dengan pembelajaran mengonstruksi teks negosiasi telah mengalami perubahan. Perubahan tersebut dikarenakan setelah diterapkannya model pembelajaran problem based learning peserta didik tertarik untuk mengikuti pembelajaran mengonstruksi teks negosiasi dikarenakan berangkat dari permasalahan yang dialami oleh peserta didik 
sendiri yang dapat diselesaikan melalui negosiasi. Adapun peserta didik yang kurang senang dan bersemangat dalam pembelajaran mengonstruksi teks negosiasi sebelum menggunakan model pembelajaran problem based learning, setelah diterapkannya model pembelajaran problem based learning peserta didik mengalami perubahan, sehingga peserta didik merasa senang dan bersemangat dalam mengikuti pembelajaran mengonstruksi teks negosiasi. Selain itu, peserta didik yang tidak dapat mempresentasikan hasil pekerjaannya di depan guru dan temantemannya mengalami perubahan menjadi berani mempresentasikan hasil pekerjaannya di depan guru dan teman-temannya. Ketika guru sedang menyampaikan materi kepada peserta didik, yang awalnya peserta didik pasif dalam pembelajaran mengonstruksi teks negosiasi, mengalami perubahan setelah diterapkan model pembelajaran problem based learning menjadi terlibat aktif dan ikut serta dalam mengikuti pembelajaran mengonstruksi teks negosiasi. Berdasarkan uraian tersebut dapat disimpulkan bahwa secara keseluruhan peserta didik mampu menunjukkan perubahan sikap dan motivasi belajar ke arah yang positif. Tingkah laku negatif yang ditunjukkan saat pembelajaran sebelum menggunakan model pembelajaran problem based learning telah mengalami penurunan.

Hasil wawancara terhadap peserta didik mengenai perubahan sikap dan motivasi belajar peserta didik pada siklus I dan siklus II menunjukkan bahwa dengan diterapkannya model problem based learning proses dalam pembelajaran mengonstruksi teks negosiasi mengalami perubahan perilaku ke arah yang lebih baik. Data wawancara diambil dari 3 peserta didik dengan kategori berbeda, yaitu peserta didik yang mendapat nilai tinggi, peserta didik yang mendapat nilai sedang, dan peserta didik yang mendapat nilai kurang. Hal ini dilakukan untuk mengetahui sikap belajar peserta didik terhadap pembelajaran mengonstruksi teks negosiasi setelah pembelajaran menggunakan model pembelajaran problem based learning. Berdasarkan wawancara yang dilakukan terhadap tiga peserta didik tersebut, masing-masing peserta didik mempunyai jawaban yang berbeda. Peserta didik yang mendapatkan nilai tinggi menjawab semua pertanyaan dengan jawaban ya karena peserta didik sangat tertarik dengan pembelajaran mengonstruksi teks negosiasi, sedangkan peserta didik yang mendapatkan nilai sedang menjawab semua pertanyaan dengan jawaban kadang-kadang karena peserta didik sedikit tertarik, dan peserta didik yang mendapatkan nilai kurang menjawab semua pertanyaan dengan rata-rata jawaban tidak karena peserta didik kurang tertarik dengan pembelajaran mengonstruksi teks negosiasi. Selain wawancara terkait dengan sikap terdapat wawancara motivasi belajar peserta didik pada siklus I dan siklus II. Hal ini dilakukan untuk mengetahui motivasi peserta didik terhadap pembelajaran mengonstruksi teks negosiasi yang menggunakan model pembelajaran problem based learning. Selama proses pembelajaran peserta didik tertarik dalam pembelajaran mengonstruksi teks negosiasi dan penggunaan model pembelajaran problem based learning karena dapat memudahkan peserta didik dalam mengonstruksi teks negosiasi berdasarkan permasalahan nyata sehingga peserta didik merasa tertarik dan antusias dalam proses pembelajaran. Dari hasil wawancara siklus I dan siklus II dapat diketahui bahwa ketiga peserta didik pada dasarnya merasa senang dan tertarik mengikuti pembelajaran mengonstruksi teks negosiasi yang menggunakan model pembelajaran problem based learning. Menurut mereka pembelajaran mengonstruksi teks negosiasi yang menggunakan model pembelajaran problem based learning menarik dan sangat menyenangkan.

Perubahan perilaku peserta didik juga diketahui dari hasil angket. Adapun hasil angket terdiri atas sikap dan motivasi belajar peserta didik. Hasil angket sikap belajar peserta didik selama proses pembelajaran pada siklus I dan siklus II mengalami perubahan. Perubahan tersebut dapat diketahui dari hasil angket sikap peserta didik selama mengikuti pembelajaran mengonstruksi teks negosiasi yang menggunakan model pembelajaran problem based learning mengalami peningkatan yang lebih positif. Hal tersebut membuktikan bahwa pembelajaran mengonstruksi teks negosiasi dengan menggunakan model pembelajaran problem based learning dapat meningkatkan sikap belajar peserta didik. Selain angket sikap terdapat angket motivasi belajar peserta didik yang digunakan untuk menilai pada saat pembelajaran berlangsung. Hasil angket motivasi belajar peserta didik selama proses pembelajaran mengalami perubahan. Perubahan tersebut dapat diketahui dari perilaku peserta didik selama mengikuti pembelajaran mengonstruksi teks negosiasi yang menggunakan model pembelajaran problem based learning mengalami peningkatan yang lebih positif. Hal tersebut membuktikan bahwa keterampilan mengonstruksi teks negosiasi dengan menggunakan model pembelajaran problem based learning dapat meningkatkan hasil angket motivasi belajar peserta didik.

\section{Simpulan}

Penelitian ini dilakukan dalam tiga tahap, yaitu prasiklus, siklus I, dan siklus II, Tahap prasiklus 
dilakukan untuk mengetahui kondisi awal peserta didik dalam pembelajaran mengonstruksi teks negosiasi, Berdasarkan hasil penelitian prasiklus, dapat diketahui bahwa selama proses pembelajaran guru tidak menggunakan model pembelajaran dan media pembelajaran karena penerapan sistem UKBM, sehingga banyak peserta didik yang pasif dan kurang antusias dalam mengikuti pembelajaran mengonstruksi teks negosiasi, Peserta merasa bosan dengan pembelajaran yang bersifat monoton karena setiap hari hanya mengerjakan tugas-tugas yang telah di susun dalam buku UKBM, Keadaan tersebut memengaruhi hasil akhir mengonstruksi teks negosiasi karena masih banyak peserta didik yang nilainya masih rendah dan di bawah KKM, Setelah dilaksanakan tindakan siklus I dan siklus II, peserta didik menjadi sangat antusias dan tertarik untuk mengikuti pembelajaran mengonstruksi teks negosiasi yang menggunakan model pembelajaran problem based learning, peserta didik lebih mampu menuangkan gagasan dalam teks negosiasi karena berangkat dari permasalahan pribadi peserta didik sehingga berpengaruh pula pada hasil yang semakin baik.

Berdasarkan hasil penelitian pada prasiklus, siklus I, dan siklus II diketahui adanya peningkatan dalam pembelajaran mengonstruksi teks negosiasi yang menggunakan model problem based learning, Hal tersebut dapat diketahui dari hasil tes yang diperoleh peserta didik pada prasiklus, siklus I dan siklus II. Pada prasiklus peserta didik mendapat nilai rata-rata kelas sebesar 69,26 dengan kategori kurang, pada siklus I terjadi peningkatan mencapai 74,26 dengan kategori cukup. Peningkatan pada prasiklus ke siklus I sebesar 7,22\%, Adapun nilai rata-rata pada siklus II mencapai 85,03 dengan kategori baik, sehingga peningkatan yang terjadi pada siklus I ke siklus II sebesar $14,50 \%$. Hal tersebut membuktikan bahwa hasil mengonstruksi teks negosiasi peserta didik terus mengalami peningkatan dari prasiklus, siklus I dan siklus II. Pada aspek penilaian teks negosiasi kekreatifan ide memiliki peningkatan yang cukup tinggi dibandingkan yang lain setelah penerapan model problem based learning. Hal tersebut disebabkan peserta didik mulai terbuka pikirannya untuk menemukan permasalahan di lingkungan sekitar yang mampu diselesaikan melalui negosiasi. Sedangkan aspek lain seperti ejaan dan tanda baca, isi teks, kebahasaan teks, dan struktur teks juga mengalami peningkatan pada setiap siklus meskipun tidak sesignifikan aspek kekreatifan ide karana ejaan dan tanda baca, kebahasaan memang perlu dilatih terus menerus supaya hasil tulisan peserta didik semakin lama semakin membaik.
Peserta didik juga mengalami perubahan perilaku ke arah yang positif selama mengikuti pembelajaran mengonstruksi teks negosiasi dengan menggunakan model pembelajaran problem based learning. Perubahan tersebut ditunjukkan dengan sikap dan perilaku peserta didik sebelum mengikuti pembelajaran peserta didik tidak aktif, tidak bersemangat, dan tidak memiliki motivasi belajar saat pembelajaran bahasa Indonesia dengan sistem UKBI tetapi ketika mengikuti pembelajaran mengonstruksi teks negosiasi peserta didik mengalami perubahan ke arah yang lebih baik. Peserta didik sangat antusias mengikuti pembelajaran, keaktifan peserta didik juga meningkat dengan demikian motivasi belajar peserta didik menjadi bertambah pula, Peserta didik bersemangat dalam mencari permasalahan di lingkungan sekitar untuk diselesaikan melalui jalan negosiasi. Mereka bahkan berlomba lomba untuk menemukan permasalahan yang menarik dan unik yang berbeda dari peserta didik lain. Oleh karena itu, ketika proses mengonstruksi juga berlangsung menyenangkan karena peserta didik berusaha menyelesaikan permasalahan tersebut dengan negosiasi. Sikap dan perilaku peserta didik dapat dibuktikan dengan adanya hasil observasi, wawancara, angket, dan dokumentasi

\section{Persantunan}

Peneliti mengucapkan terima kasih kepada pihak-pihak yang telah membantu dan terlibat dalam penelitian artikel ini, yaitu guru bahasa Indonesia SMA Negeri 7 Malang dan dosen pembimbing lapangan serta rekan-rekan PPG Prajabatan Bersubsidi Jurusan Pendidikan Bahasa dan Sastra Indonesia Universitas Muhammadiyah Malang.

\section{Daftar Pustaka}

Argaw, Aweke Shishigu,, dkk. (2016). The Effect of Problem Based Learning (PBL) Instruction on Students' Motivation and Problem Solving Skills of Physics, EURASIA Journal of Mathematics Science and Technology Education Addis Ababa University. Ethiopia. 3(1). 858-871.

Badan Penelitian dan Kebudayaan. (2013). Bahasa Indonesia Ekspresi Diri dan Akademik. Jakarta: Kementerian Pendidikan dan Kebudayaan.

Badan Penelitian dan Pengembangan. (2013). Kurikulum 2013 Kompetensi Dasar SMA/MA. Jakarta: Kementerian Pendidikan dan Kebudayaan.

Huda, Miftahul. (2014). Model-Model Pengajaran dan Pembelajaran. Yogyakarta: Pustaka Pelajar. 
Kemmis, S \& Mc Taggart, R,. (1992). The Action Research Planner. Australia: Deakin University Press.

Lee, Jean S. dkk. (2014). "Taking a Leap of Faith: Redefining Teaching and Learning in Higher Education Through Project Based Learning”. Interdisciplinary Journal of Problem-Based Learning 8(2). 8- 17.

Lewicki, Roy J,, Bruce Barry, dan David M, Saunders, (2012). Negosiasi. Jakarta: Salemba Humanika.

Simone, Christina De. (2014). Problem-Based Learning in Teacher education:Trajectories of Change. International Journal of Humanities and Social Science. 4(12).

Subyantoro. (2012). Penelitian Tindakan Kelas. Semarang: Unnes PRESS.
Sudjana, (2005). Metoda Statistika Edisi ke-6. Bandung: Tarsito.

Sugiyono. (2010). Metode Penelitian Pendidikan. Bandung: Alfabeta.

Sanjaya, Wina. (2006). Strategi Pembelajaran Berorientasi Standar Proses Pendidikan. Jakarta: Kencana.

Sutrisno dan Kusmawan Ruswandi. (2007). Modul Melakukan Negosiasi Bisnis dan Manajemen. Sukabumi: Yudhistira.

Tarigan, Henry Guntur. (2008). Berbicara Sebagai Suatu Keterampilan Berbahasa, Bandung: Angkasa.

Yin, Khoo Yin et al. (2011). Collaborative Problem Solving Methods towards Critical Thinking. I International Education Studies. 4(2). 58-62 